\title{
Producenten, KONSTNÄREN OCH FORMGIVAREN REFLEXIONER KRING TRE ROLLER
}

\author{
Eva Persson
}

"Endast en konstnär kan genom sin tolkning omforma en idé till en visuell utställning."

Uttryckte jag mig verkligen så kategoriskt? frågar jag mig, när jag läser Ole Strandgaards presentation av mitt föredrag i seminarieprogrammet*. Jag tänker på några utställningar som jag sett och som jag vill kalla verkliga "konstverk" - utan att någon professionell konstnär mig veterligen varit med om att skapa dem. Men eftersom konstnärlig gestaltning till skillnad frän formgivning intresserar mig $i$ mitt yrke som utställningsproducent, godtar jag Oles påstående. Provisoriskt. Det fär bli den tes, som jag prövar och fantiserar omkring $i$ denna artikel.

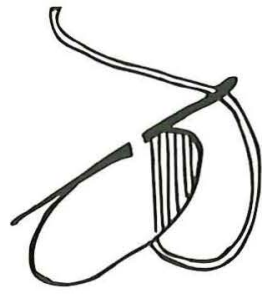

Min uppfattning - och den stärktes under seminariet i Holstebro - är att tjänstemännen $\mathrm{i}$ våra museer (möjligen med undantag för konstmuseerna) är så besatta inte bara av att berätta utan av plikten att återge ett visst i förväg fastlagt innehåll att de glömmer det viktigaste: utan form finns inget innehåll!
Nyligen läste jag en intervju med den isländske författaren Einar Kárason. Även en så genuin berättare som han sätter bokstaven och texten före innehållet. Knut Hamsun är hans ideal: "Han är som bäst, när han inte har något att berätta om. Då återstår bara berättandets egen magi, att skapa en verklighet, inget annat."

Hamsuns kortroman "Under höststjärnan« är en sådan berättelse med "försumbart innehåll«. Jag läser den och funderar över, vad Hamsuns textverklighet skulle motsvara i utställningens form. På - låt oss säga - ett länsmuseum med stadshistoriska samlingar (eftersom kampen mellan stad och land är ett av Hamsuns återkommande teman). 
48 Utställningen som »skapad verklighet" måste ånyo och ånyo prövas - även av dem som brinner av begär att berätta allt! Formen måste på ett positivt sätt uppfattas som ett motstånd.

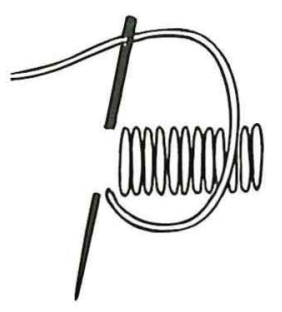

Utställningen är ett allkonstverk, ett multimedium. Ja, men man gör det lätt för sig, om man därmed likställer alla inblandade medarbetares eller professioners inflytande över det slutgiltiga resultatet. Jag föreställer mig att regissören på en teater först väljer pjäsen som skall sättas upp. Därefter utses skådespelare och scenograf. Teatermannen - eller - teaterkvinnan börjar alltså med orden, har författarens "text" som utgångspunkt. Utställningsmänniskan museernas motsvarighet till regissör kan här kallas producent - borde börja med "bilden", med en vision av utställningens uttryck i rummet och välja den som skall göra den visuella gestaltningen innan texten är spikad. Ty "bilden" bör styra "texten " på utställningsgolvet.

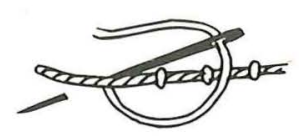

På seminariet var det intressant att lyssna till scenografen Peter Holm som sade att han inte ville veta för mycket, när han skulle börja arbeta med en utställning. Peter Holm har som bekant varit med om att förnya och förhöja den kulturhistoriska museiutställningen först vid Landskrona museum och nu på Kulturen i Lund. Från min egen praktik kan jag berätta om Lars Kleen, som skapade utställningen Maskin makt. Utgångspunkten var min synopsis, som beskrev hur teknisk utveckling och produktionsteknik förändrade människornas arbete under industrialismen i Sverige. Jag hade valt att illustrera utvecklingen utifrån vävningens och vävarnas horisont. Vi var överens om synopsis, Lars Kleen och jag, men snart insåg jag att konstnären struntade i de följande, mer detaljerade utställningsmanus, som jag sände honom. I hans ateljé såg jag mina brev med manus ligga oöppnade. Jag fick lära mig att förstå när utställningens egen verklighet tar över och konstnären måste följa andra direktiv än den alltför nitiske historieberättarens. Pà samma satt kan jag erinra mig produktionen av utställningen Land du välsignade. Den skulle handla om "industrialismens genombrott, arbetarnas miljöer och folkrörelsernas framväxt i Sverige 1850-1915.« Ett mastigt innehåll, som det borde ta lång tid att sätta sig in i. Men redan efter tre sammanträden, där två etnologer och en historiker i grova drag beskrev utställningens innehållsliga tyngdpunkter, levererade konstnären, den då unge skulptören Anders Åberg, en underbar modell av hela utställningen. Det var efter denna modell som utställningen realiserades. Vi etnologer behövde i fortsättningen bara förse konstnären med föremål och fotografier, och historikern 
log förtjust varje gång han kom för att leverera nya manus. Han tittade på modellen och fann där redan gestaltat vad han skulle tala om eller det han skulle skriva om till nästa gång vi möttes. Men historikerns arbete var inte bortkastat. Vi samlade det $\mathrm{i}$ en praktfull katalog som innehöll det som passar en skriven text, men som utställningskroppen inte tålde, som var artfrämmande, och som konstnären därför måste stöta bort.

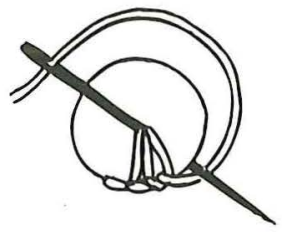

På seminariet - i diskussionen efter mitt föredrag - påpekade en deltagare, att varken Land du välsignade eller Maskin makt såg så mycket annorlunda ut än museiutställningar i gemen och att det faktum att konstnärer engagerats tydligen inte förändrat något. Bortsett från att dessa utställningar måste bedömas utifrån den tid då de tillkom, på 1970-talet, att tiden hunnit i kapp dem, och att den formmässigt mer tillgängliga och innehållsmässigt mindre kontroversiella Land du välsignade blev stilbildande för de nya basutställningarna i svenska museer tio år framåt $\mathrm{i}$ tiden, kan jag ge kritikern rätt. Det finns nämligen en risk, när man i museivärlden engagerar konstnärer och - vilket också jag gjorde förelägger dem färdiga synopsis. Såväl Land du välsignade som Maskin makt var ju genom sina långa, raka perspektiv och linjära utvecklingsbeskrivningar typiska akademiska diskurser. Utan att då vara riktigt medveten om det försatte jag
Hur överlämnar man ett utställningsuppdrag, så att konstnären inte reduceras till formgivare? Hur ser det manus ut, som låter konstnären behålla sin frihet att skapa utifrån ett eget, inre behov? Nyligen ombads jag att på Arbetets museum producera en utställning på basis av de socialarbetarminnen, som Arbetets museum samlat in tillsammans med Nordiska museet och Tjänstemännens arkiv och museum. Jag läste några av dessa minnen och fastnade för ett av dem. Det är omfattande och självutlämnande, ett livsöde snarare än ett arbetarminne, skrivet av en femtitvåårig socialsekreterare. Jag har på intuition snarare än efter noggranna utredningar överlämnat detta manus till en ung konstnär, Carin Ellberg. Hon läste texten och ville sammanföras med författaren. Det finns utom könet inte mycket som förenar dessa kvinnor - varken ålder, klassmässig bakgrund, utbildning eller yrke. Men texten är så rik, så öppen för möjliga tolkningar, har så många ingångar och utgångar att den inte borde klavbinda en konstnär. I stället borde det vara underlag för en utställning som, liksom det goda porträttet, bär prägel både av målaren och modellen. Min egen roll i den här 
50 produktionen är ännu inte utstakad. Det är ju också en ny erfarenhet, en ny kunskap om producentarbetet, som jag är ute efter. $^{1}$

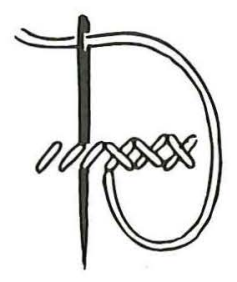

Formgivare vill jag använda, då innehållet är av överordnad betydelse, då jag träffar på ett manus med ett exakt och entydigt innehåll. I ett sådant projekt låter man författaren och inte konstnären vara den drivande. Kalejdoskopet öppnar sig - en utställning om mötet mellan bild och matematik blev en sådan utställning för mig. En ung engelsman, verksam som mellanstadielärare i Sverige, kom till Riksutställningar för att vi skulle hjälpa honom att sprida hans, för svenska skolan kontroversiella idéer om sambanden mellan bild och matematik. Han ville visa hur dessa samband kunde förändra undervisningen $\mathrm{i}$ många skolämnen och göra lektionerna nöjsamma och roliga. Jag gillade hans pedagogik, men framför allt såg jag, att de redskap, som han vill utveckla för sin undervisning, hade klara rumsliga - det vill säga utställningsmässiga - kvalitéer. Om bara de fick en vacker formgivning! Så jag kontaktade en arkitekt, Stefan Alenius, för formningen, gestaltningen av utställningen. Stefan har ett, i ovanligt hög grad, konstnärligt förhållande till sitt yrke, det hade jag sett och uppskattat i hans arkitekturdebatterande utställningar på Konstakademien. Icke desto mindre förstod jag, att han var van att lyssna till en beställare, att formge efter behov.

Att samarbeta med en formgivare eller snarare att vara ett mellanled mellan en manusförfattare och en formgivare kräver ett merarbete av producenten, främst när det gäller att analysera föremål och texter. Kanske får producenten i en sådan produktion ett större konstnärligt inflytande över helheten. Man blir både regissör och dramaturg - för att nu låna termer från det mer utvecklade teatermediet. I vilket fall som helst gav arbetet med Kalejdoskopet öppnar sig mig nya, kreativa uppgifter. Detta gav mersmak, men också - i de följande produktionerna - anledning till nya reflexioner. Vem skriver manus och hur skall det se ut, när man arbetar med en formgivare? Att t.ex. vara både manusförfattare och producent, när man valt en formgivare för den visuella gestaltningen, är inte bra. Man ser i resultatet samma svagheter som i en teaterförställning regisserad av pjäsförfattaren.

Som producent kan man reducera en konstnär till formgivare och ge en formgivare alltför stort innehållsmässigt ansvar. Det kan ske omedvetet, man blir klar på misstagen först efteråt, eller när konstnären $\mathrm{i}$ vredesmod lämnar produktionen åt sitt öde! Men man kan också be en arkitekt eller formgivare kreera rollen av konstnär i en produktion, liksom man kan

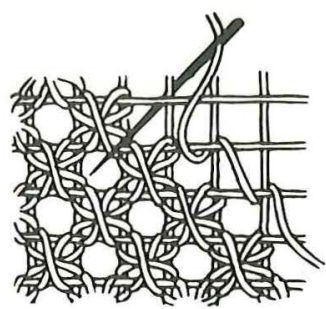


komma överens med en konstnär att $\mathrm{i}$ en viss produktion inta formgivarens roll.

En utställningsproducent måste vilja reflektera över rollfördelningar i varje enskild produktion, kunna analysera behoven av professionella insatser, se när och var det krävs specialistingrepp. Men en producent måste också uppfatta, när en utställning står på egna amatöristiska ben. De skälver kanske, ty de för in helt nytt material, en ny verklighet på marmorgolven. En sådan händelse var "Göteborgaren i ett rum och kök" på Historiska museet i Göteborg 1970.

Men samma skälvning kan gå igenom en utställning med så konventionellt museimaterial som 1800-tals broderier. På Lidköpings Hantverks- och Sjöfartsmuseum förvandlades 1983 en stor inventering av Västgötabroderier $i$ rött och blått till en ny verklighet - på utställningsgolvets premisser. Liksom ord är ord, fast de stavas olika och på sätt kan bilda en mening, var broderierna broderier med olika storlek, funktion och mönster som genom själva det överdådiga utställningsarrangemanget omvandlade rummet till en berättelse om hemlighetens kultur, där underläge förvandlas till överläge och dårskap blir högsta klokskap. Eller kanske makt och motstånd! Det fanns i broderiutställningen liksom i Göteborgaren i ett rum och kök en berusande berättarglädje - till skillnad från det pliktmässiga, mekaniska berättandet, som förstör de flesta museiutställningar. Och kanske är det bara där - i glädjen, nyfikenheten och lusten - som utställningen kan få sin form. Oavsett om drivkraften finns hos konstnären, formgivaren, en hemslöjdskonsulent i Västergötland eller en akademiskt utbildad etnolog vid ett historiskt museum.

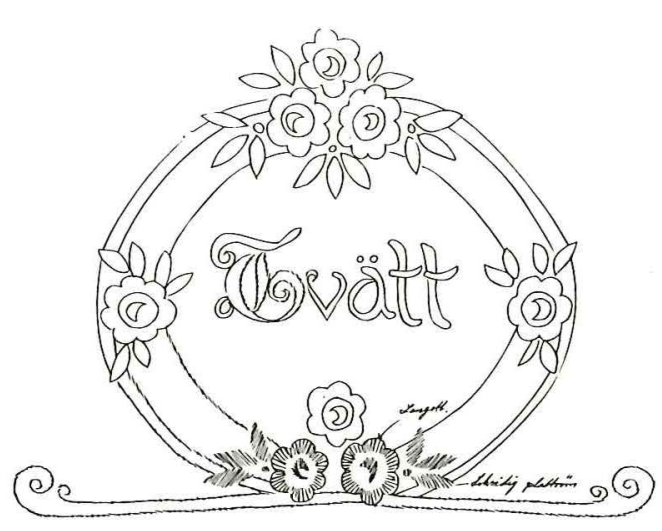

Vinjetterna är tagna ur katalogen till utställningen "Västgöta broderier $i$ rött och blàtt».

\section{SUMMARY}

Reflections on the roles of producer, artist and designer in an exbibition

The author is one of the best-known producers of exhibitions for museums. She worked for twenty years for 'Swedish Travelling Exhibitions', then accepted the position of 'art director' for the new Museum of Work in Norrköping. After completing its much discussed opening exhibition, 'The Sixth Sense', and some minor exhibitions she left Norrköping and now works as a freelance producer in Stockholm. She is the author of the book Utställningsform ('Exhibition form', 1994). In the paper, presented in 1992 at Holstebro, Denmark, she discusses the roles of the various specialists involved in the production of exhibitions - the producer, the artist and the designer. The startingpoint is the observation that the exhibition is a 'created reality' and that, without a form, a message is never discernable. Though the exhibition with its combination of many media must necessarily be the result of teamwork you cannot regard all the members of the team as being of equal importance. In a 
52 production for the stage, the director must have a vision of the totality of the play which all the participating specialists must accept and to which they must subordinate themselves. It is the same with the exhibition producer who must set out with a clear idea of what he or she wants to achieve. This mental picture must govern the production.

The author has relied on artists to give form to such governing pictures and has noted that they resist preparatory briefings that are too detailed, as they start the process of sketching 'the big form', the structure which will serve as frame and skeleton for the production. She is constantly struggling with the problem of how to offer a manuscript to the artist which allows a maximum of freedom and as well allows the artist to develop ideas out of his or her individual need for expression.

When the manuscript has an exact and special theme the content is of superior importance - here the author must be given the priority and the form becomes the task of a designer - or an architect. As exhibitions always present spatial problems architects are possible partners for the producer. The interplay between producer, author, artist and designer is always complex and the assignment of responsibilities must be carefully negotiated. A producer may reduce an artist to the role of the designer or give to the designer too much responsiblity for the development of the theme. To combine the roles of author and producer, when you have chosen a designer for the visual form, may be disastrous, just as when a playwright wants to direct the performance.

In each production, especially when amateurs are involved, the producer must scrupulously reflect on the division of roles. A producer must be able to withdraw from professional interference when faced with the spontaneity of naive creativity, the genuine joy in telling a story visually. This is so rare and contrasts vividly with the anonymous, dutiful and mechanical visuals that destroy most museum exhibitions.
NOTER

* Texten bygger på en föreläsning i Holstebro 6 sept. 1992

1. Eva Persson ger i sin bok Utställningsform (Carlssons förlag, Stockholm 1994) med en bild och en bildtext, s. 142. en glimt av hur utställningen blev. Boken anmäldes i Nordisk Museologi 1994/2, s. 136

Eva Persson är numera frilansande utställningsproducent. Hon arbetade 1967-89 som producent vid Riksutställningar, Stockholm, och 1989-93 som konstnärlig ledare och producent vid Stiftelsen Arbetets Museum i Norrköping. Hennes bok 'Utställningsform' utkom 1994.

Adr: Tengdablsgatan 16, S-116 41 Stockholm 